PALGRAVE

HANDBOOKS
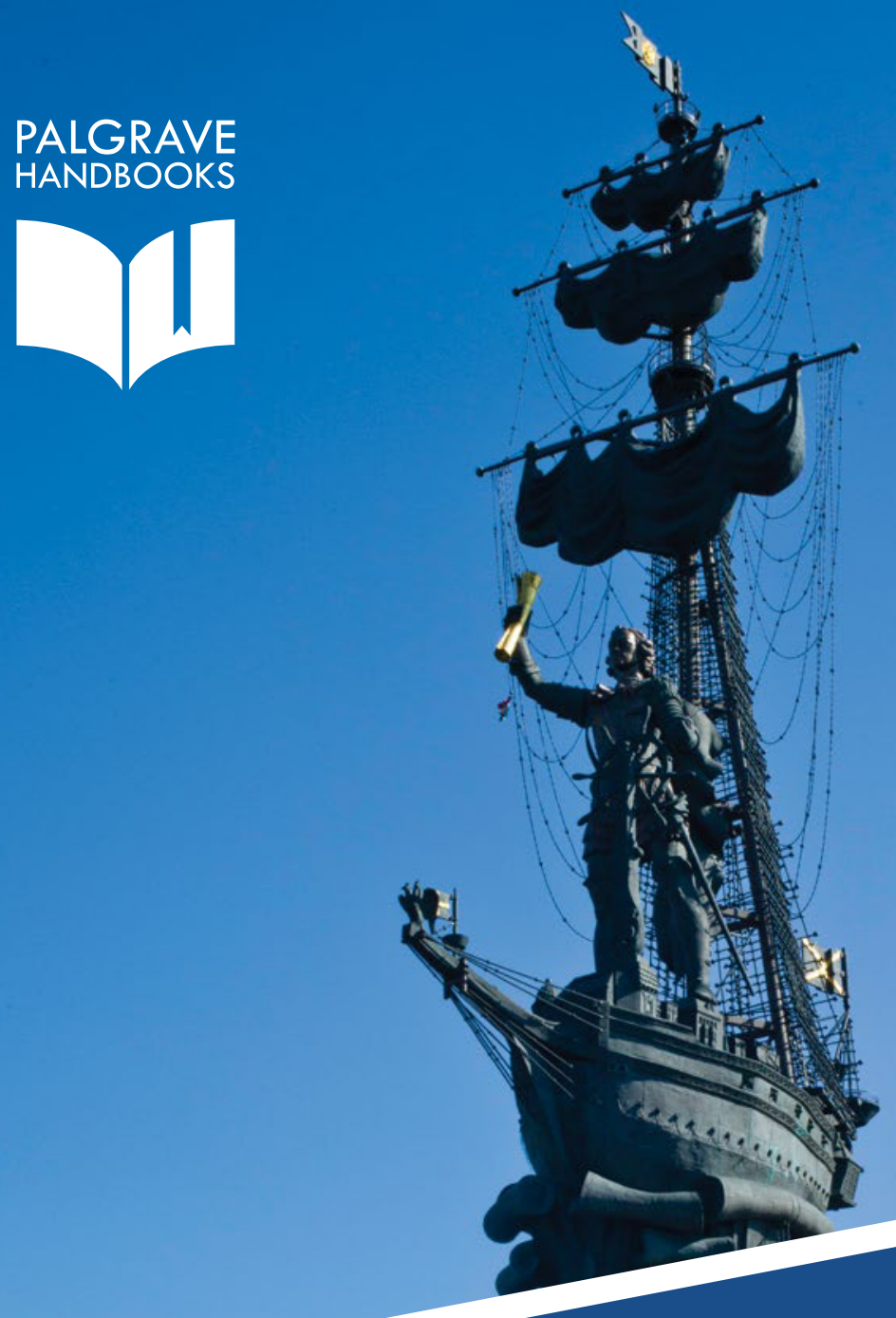

\title{
THE PALGRAVE HANDBOOK OF STATE-SPONSORED HISTORY AFTER 1945
}

Edited by Berber Bevernage and Nico Wouters

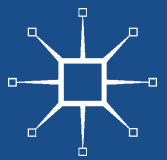


The Palgrave Handbook of State-Sponsored

History After 1945 
Berber Bevernage - Nico Wouters

Editors

\section{The Palgrave \\ Handbook of State- \\ Sponsored History \\ After 1945}

palgrave
macmillan 


\section{Editors}

Berber Bevernage

Department of History

Ghent University

Ghent, Belgium

\author{
Nico Wouters \\ CEGESOMA (Belgian State Archives) \\ Brussels, Belgium
}

\section{ISBN 978-1-349-95305-9 https://doi.org/10.1057/978-1-349-95306-6}

Library of Congress Control Number: 2017950700

(C) The Editor(s) (if applicable) and The Author(s) 2018

The author(s) has/have asserted their right(s) to be identified as the author(s) of this work in accordance with the Copyright, Designs and Patents Act 1988.

This work is subject to copyright. All rights are solely and exclusively licensed by the Publisher, whether the whole or part of the material is concerned, specifically the rights of translation, reprinting, reuse of illustrations, recitation, broadcasting, reproduction on microfilms or in any other physical way, and transmission or information storage and retrieval, electronic adaptation, computer software, or by similar or dissimilar methodology now known or hereafter developed. The use of general descriptive names, registered names, trademarks, service marks, etc. in this publication does not imply, even in the absence of a specific statement, that such names are exempt from the relevant protective laws and regulations and therefore free for general use.

The publisher, the authors and the editors are safe to assume that the advice and information in this book are believed to be true and accurate at the date of publication. Neither the publisher nor the authors or the editors give a warranty, express or implied, with respect to the material contained herein or for any errors or omissions that may have been made. The publisher remains neutral with regard to jurisdictional claims in published maps and institutional affiliations.

Cover credit: (c) Sura Ark/Contributor/Getty Images

Printed on acid-free paper

This Palgrave Macmillan imprint is published by Springer Nature

The registered company is Macmillan Publishers Ltd.

The registered company address is: The Campus, 4 Crinan Street, London, N1 9XW, United Kingdom 


\section{Contents}

1 State-Sponsored History After 1945: An Introduction Berber Bevernage and Nico Wouters

Part I Memory Laws and Legislated History

Overview chapter:

2 Laws Governing the Historian's Free Expression Antoon De Baets

Case chapters:

3 Writing History Through Criminal Law: State-Sponsored Memory in Rwanda

Pietro Sullo

4 French Memory Laws and the Ambivalence About the Meaning of Colonialism

Stiina Löytömäki

5 History Watch by the European Court of Human Rights Pierre-Olivier de Broux and Dorothea Staes

6 Legislated History in Post-Communist Lithuania

Tomas Balkelis and Violeta Davoliūtè 


\section{Part II Archives and Libraries}

Overview chapter:

7 Archives, Agency, and the State

Trudy Huskamp Peterson

Case chapters:

8 Open Archives to Close the Past: Bulgarian Archival Disclosure on the Road to European Union Accession

Niké Wentholt

9 Archives and Post-Colonial State-Sponsored History:

A Dual State Approach Using the Case of the "Migrated Archives"

Michael Karabinos

10 The "Cleansing" of Croatian Libraries in the 1990s and Beyond or How (Not) to Discard the Yugoslav Past

Dora Komnenović

Part III Research Institutes and Policies

Overview chapter:

11 State Authority and Historical Research: Institutional Settings and Trends Since 1945

Lutz Raphael

Case chapters:

12 Official History Reconsidered: The Tadhana Project in the Philippines

Rommel A. Curaming

13 History Riding on the Waves of Government Coalitions: The First Fifteen Years of the Institute of National Remembrance in Poland (2001-2016)

Idesbald Goddeeris 
Part IV Schools, Curricula and Textbooks

Overview chapter:

14 History in Schools

Peter Seixas

Case chapters:

15 History Teaching for the Unification of Europe:

The Case of the Council of Europe

Luigi Cajani

16 Teaching History Under Dictatorship: The Politics of Textbooks and the Legitimation of Authority in Mobutu's Zaire

Denise Bentrovato

17 The "National Dream" to Cultural Mosaic: State-Sponsored History in Canadian Education

Lynn Lemisko and Kurt Clausen

18 China's History School Curricula and Textbook Reform in East Asian Context

Gotelind Müller

19 Teaching History in Israel-Palestine Achim Rohde

Part V Museums and Musealisation

Overview chapter:

20 History Museums

Ilaria Porciani

Case chapters:

21 "State-Supported History" at the Local Level: Ostdentsche Heimatstuben and Expellee Museums in West Germany Cornelia Eisler 
22 State Agency and the Definition of Historical Events: The Case of the Museo de La Memoria $\Upsilon$ Los Derechos Humanos in Santiago, Chile

Patrizia Violi

23 History Wars in Germany and Australia: National Museums and the Relegitimisation of Nationhood

Christian Wicke and Ben Wellings

Part VI Memorials, Monuments and Heritage

Overview chapter:

24 Memorials and State-Sponsored History

Shanti Sumartojo

Case chapters:

25 Spaces of Nationhood and Contested Soviet War Monuments in Poland: The Warsaw Monument to the Brotherhood in Arms

Ewa Ochman

26 Heritage Statecraft: Transcending Methodological

Nationalism in the Russian Federation

Gertjan Plets

Part VII Courts, Tribunals and Judicial History

Overview chapter:

27 The State, the Courts, and the Lessons of History: An Overview, with Reference to Some Emblematic Cases Richard J. Golsan

Case chapters:

28 The Historian's Trial: John Demjanjuk and the Prosecution of Atrocity 
29 Germany Versus Germany: Resistance Against Hitler, Postwar Judiciary and the 1952 Remer Case

Vladimir Petrović

30 Historical Testimony for the Government in US v. Philip Morris, et al.

Ramses Delafontaine

31 A One-Sided Coin: A Critical Analysis of the Legal Accounts of the Cypriot Conflicts

Nasia Hadjigeorgiou

Part VIII Truth Commissions and Commissioned History

Overview chapter:

32 Truth Commissions and the Construction of History Eric Wiebelhaus-Brahm

Case chapters:

33 Truth Commissions and the Politics of History: A Critical Appraisal

Stephan Scheuzger

34 The Brazilian National Truth Commission (2012-2014) as a State-Commissioned History Project

Nina Schneider and Gisele Iecker de Almeida

35 The 9/11 Commission Report: History Under the Sign of Memory

Oz Frankel

36 Truths of the Dictatorship: Chile's Rettig and Valech Commissions as State-Sponsored History 
Part IX Historical Expert Commissions and Commissioned History

Overview chapter:

37 Historical Expert Commissions and Their Politics Eva-Clarita Pettai

Case chapters:

38 Reconstituting the Dutch State in the NIOD Srebrenica Report

Erna Rijsdijk

39 Memory Institutions and Policies in Colombia:

The Historical Memory Group and the Historical

Commission on the Conflict and Its Victims

Martha Cecilia Herrera, José Gabriel Cristancho Altuzarra and

Carol Juliette Pertuz

40 Diversified and Globalized Memories: The Limits of State-Sponsored History Commissions in East Asia

Seiko Mimaki

41 Switzerland's Independent Commission of Experts:

State-Sponsored History and the Challenges of Political

Partisanship

Alexander Karn

Part X Official Apologies and Diplomatic History

Overview chapter:

42 Historical State Apologies

Až̌uolas Bagdonas

Case chapters:

43 Apology Failures: Japan's Strategies Towards China and Korea in Dealing with Its Imperialist Past 
44 The "Apology to Australia's Indigenous Peoples" in Its Historical Context

Francesca Dominello

45 Narrative Robustness, Post-Apology Conduct, and

Canada's 1998 and 2008 Residential Schools Apologies Matt James

Index 